PART 1

\title{
$\bullet$
}


Paul Heger - 9789004277113

Downloaded from Brill.com04/26/2023 10:04:43AM via free access 


\section{The Creation Narrative and the Status of Women}

\subsection{Introduction}

This chapter begins with a close analysis of the biblical texts of Creation, identifying the key differences between the narrative in Gen 1 and that in Gen 2, and continues by analysing the textual problems in Gen 2, making reasonable deductions regarding its attitude towards women. A particular focus will be whether the purpose of woman's creation as man's helper, and the scriptural facts of her later creation and her creation from man, should to any extent imply her inferiority. Citing the opinions of traditional commentators and modern scholars, the study will argue in the negative on this question. On the other hand, the woman's creation from Adam, his declaration that she is bone of his bone and flesh of his flesh, and consequently the derivation of her name from this reality affirm that the maxim "they will become one flesh" indicates woman's lack of a separate legal identity, with all the legal and practical ramifications this implies. This does not, however, create a personal inequality for women. The legal distinction between men and women is due to their distinct functions, not because of any superiority or inferiority. In the course of developing this thesis, scholarly and commentary opinions will be cited.

I shall also consider and compare Qumranic and rabbinic opinions on these issues, highlighting agreements and disagreements between them. Qumran writings do not generally interpret the scriptural texts, nor did they leave a collection of midrashim comparable to those of the rabbinic literature. Therefore, we can only infer the philosophy underlying Qumran's attitude towards women from the relevant available writings. Conversely, the array of midrashim and scattered interpretations of biblical verses in rabbinic writings enable us to uncover the basic philosophy guiding rabbinic scholars in their aim of formulating doctrines and halakhic rules.

\subsubsection{Key Textual Differences between the Creation Narratives of Gen 1 and 2}

Chapters 1 and 2 of Genesis present drastically different narratives of the creation of humans. As we may observe in the narrative of Gen 1:26-31, there

(C) PAUL HEGER, 2014 | DOI 10.1163/9789004277113_003 
is no difference in any respect between man and woman. The term Adam is genderless and refers to "human," not to "man." Both man and woman were created at the same time, both are in God's image, and their joint purpose is to multiply and subdue all other inferior creatures of the universe (1:27-28). God has granted to man and woman equally the right to enjoy all the products of the earth, and both are superior to all other creatures, whose right to food is restricted to specified types (1:29-30).

The narrative in Gen 2 is in stark contrast to this thoroughly egalitarian portrayal of man and woman with respect to their creation, purpose, function, and place in the universe. This second narrative became crucial to the conventional interpretation of the Creation story, together with its repercussions for women's status in Jewish and Christian societies. Unlike the clear and unambiguous Creation narrative in Gen 1, this portrayal of the creation of humankind - particularly the creation of woman; God's rationale for her purpose and function before her creation (Gen 2:18); the mode of her creation (2:21-22); and the events immediately after her creation (2:23-24) — provokes many questions, divergent interpretations, and assumptions. Whereas Gen 1 describes the simultaneous creation of man and woman, Gen 2:7 records only the creation of man; the NIV, whose translation is quoted above, correctly translates the term אדם in Gen 1:27 as "mankind" (in the modern sense of humankind) and in 2:7 as "man"; the KJV has "man" in both cases, and the LXX has $\alpha \nu \theta p \omega \pi \circ \varsigma$, usually understood as the genderless "humankind." Moreover, whereas Gen 1 emphasizes humankind's creation in God's image, Gen 2 does not mention this; though recording that God breathed into man's nostrils the breath of life, it emphasizes his creation from the dust of the ground (2:7). Scholars have noticed these and other inconsistencies and concluded that the two narratives come from two different sources, amalgamated by the redactor. ${ }^{1}$ I will therefore not consider this matter further.

\subsubsection{Textual Issues in the Creation Narrative of Gen 2}

Gen 2:18, recording God's afterthought to Adam's creation that "it is not good for the man to be alone," calls into question Scripture's general assumption of divine omniscience. ${ }^{2}$ It is also remarkable that the narrative in Gen 2 omits

1 It has generally been assumed that Gen 1 is from source P and Gen 2-3 from source J. However, this presumption creates some problems: How can one explain that the later P authors contradicted the earlier J authors?

2 Scripture does not indicate how long Adam was alone between his creation and that of Eve. A midrash in Lev. Rab. 29 records that the entire event, from Adam's creation until his expulsion from the Garden, occurred in one day, that is, the sixth day. Jubilees, however, has another 
God's conversation (or perhaps consultation) with the angels, ${ }^{3}$ recorded in Gen 1:26. Further, the literary structure of the narrative seems incongruous; the divine consideration of man's situation and consequent decision to create the woman (2:18) would logically have appeared after the man's naming of all the creatures and the realization that man is the only living creature without a partner (2:19-20). While it is evident that the phrase "I will make him a help meet for him" (2:18b) is uttered by God, it is not clear who is the subject of the phrase ולאדם לא מצא עזר כנגדו (lit. "and for the man he did not find a helper 'against' him") in 2:2ob. Is it God or Adam? And, indeed, in order to circumvent the dilemma, the NIV, like the KJV and the LXX, interprets this phrase in an undefined manner and translates it in the passive voice- - "no suitable helper was found"-although the biblical text is in the active voice. The traditional commentators Rashi and Ibn Ezra interpreted it as referring to Adam, as does Umberto Cassuto, ${ }^{6}$ following the interpretation of Abot R. Nat.; ${ }^{7}$ likewise John Hartley and Claus Westermann. ${ }^{8}$ Regarding the ramifications for the woman's status of her creation from Adam's rib, Hartley states, "just as the rib is found at the side of the man and is attached to him, even so the good wife, the rib of her husband, stands at his side to be his helper-counterpart, and her soul is

timeline. Although Jub. 2:14 follows Gen 1:27, Jub. 3:8 indicates a different date: "In the first week was Adam created, and the rib — his wife: in the second week." At any rate, according to both sources God created the woman as an afterthought.

3 See Gen. R. parsha 17 regarding God's discussion with the angels.

4 Jub. 3:4-5 "corrects" this omission.

5 Werner H. Schmidt, Die Schöpfungsgeschichte der Priesterschrift; Zur Überlieferungsgeschichte von Genesis 1, 1-1-2,4a und 2,4b-3,24 9 (Neukirchen: Neukirchener Verlag, 1973) 199, clarifies that in Gen 2:7 and 2:18, אדם refers to the specific (singular) man, not to mankind, as in previous instances. At 200, interestingly, Schmidt argues that עזר, particularly when expressed in the masculine, does not specify the purpose and gender of the helper, nor does the text of Gen 2:18 clarify what type of helper the man needs. In fact, a midrash in Abot R. Nat. Recension b, Chapter 8, quoted in note 7 below, asserts that Adam, having seen all the living creatures and given them names (Gen 2:19-20), complained to God of being the only creature without a female companion. Hence, the type and gender of the helper in 2:18 is not yet specified.

6 Umberto Cassuto, A Commentary on the Book of Genesis (trans. Israel Abrahams; Jerusalem: Magness Press, 1961) 132-33.

7 Abot R. Nat. Recension b, Chapter 8 interprets Gen 2:20 thus: Adam complained to God, that He had created companions for all His creations except for him.

8 John E. Hartley, New International Biblical Commentary: Genesis (Peabody, MA: Hendrickson, 2000) 62; Claus Westermann, Genesis: An Introduction (trans. John J. Scullion, SJ; Minneapolis, MN: Augsburg Fortress, 1992), 229. 
bound up with his." ${ }^{9}$ Cassuto continues his portrayal of the Creation event with superlatives to demonstrate Adam's joy at meeting the woman, a valuable gift from God, and his realization that he now has a helper corresponding to him. ${ }^{10}$ Cassuto depicts a fully positive ambiance created by all involved-God, Adam, and the woman - and perceives no inequality between man and woman, nor a loss of woman's individual identity by virtue of her status as a part of man, in contrast to Scripture's legal rules that indicate her to be his unequal partner.

\section{עזר כנגדו 1.2.3 Interpreting the Phrase}

However, the scriptural phrase עזר כנגדו כGen 2:18 and 2:20)—translated/ interpreted by the NIV as "a suitable helper for him"—is in fact an ambiguous expression that cannot serve as hard evidence as to the intent of its author. The word עזר "helper" does not indicate that the helper is inferior to the person helped; a helper, or "help meet" (as the KJV translates the phrase עזר כנגדו), could be either a subordinate assistant or an equal partner. And, indeed, this term has been interpreted with different allusions, as intending an equal or lower rank, according to the preconceptions of the translators/interpreters. ${ }^{11}$

$9 \quad$ Hartley, Genesis, 135 .

10 Westermann, Genesis 1-11, 228 quotes and disputes the theory of Johannes Hempel, Apoxysmata: Vorarbeiten zu einer Religionsgeschichte und Theologie des Alten Testaments: Festgabe zum 30. Juli 1961 (Berlin: De Gruyter, 1961), 198-229, that "God really meant the animals to be human companions, however, the man misused them and so God gave him as a punishment the woman who brought distress [of the Fall]." Westermann perceives the thrust of the narrative as leading "from the divine reflection, v. 18, to the accomplishment of the intent, v. 22, and its acknowledgment by the man, v. 23." We observe the extent of the blunders that scholarly preconceptions can generate: Hempel devised a theory that has no textual basis, and ignored the favourable attitude Adam displays towards Eve by naming her as the mother of all the living (Gen 3:20). This occurs after the Fall and Adam's awareness of God's punishment, demonstrating that he does not perceive Eve as the cause of their calamities. Robert D. Sacks, A Commentary on the Book of Genesis (Lewiston, NY: Edwin Mellen, 1990) 36-37, writes that Adam understands that the banishment from the Garden is not a punishment in the simple sense of the word; rather, he must leave it because "he is no longer fit to eat from the Tree of Life." He realizes, however, that "procreation must replace immortality" and that Eve "is the one who will care for the continuation of life." By naming Eve as the mother of all the living, Adam indicates his acceptance of this reality.

11 Tal Ilan, Jewish Women in Greco-Roman Palestine: An Inquiry into Image and Status (Tübingen: J.C.B. Mohr (Paul Siebeck), 1995) 11, charges Leonard Swidler, Biblical Affirmations of Woman (Philadelphia: Westminster Press, 1979), with basing his study on a biased preconception to demonstrate "Jesus' positive attitude towards women whereas that of the Hebrew Bible was negative or at best ambivalent." In my opinion, Swidler does not attribute woman's subordination and inferiority to the act of Creation; at 78 he quotes 
Ed Noort disputes the interpretation of "helper" as implying a lower rank: "the word 'help' implies neither superiority nor inferiority on the part of the person giving or receiving the aid."12 He does not, however, give adequate significance to Adam's powerful pronouncement that the woman is part of him, of his bone and flesh. Adam emphasizes the importance of this by naming her on this basis (Gen 2:23), hinting at her lack of individual identity (as becomes clear in Gen 3:16b). To avoid an interpretation contrary to this assumption of equality between male and female, Noort declares that Gen 3:16b describes the actual state of the relationship between them, rather than what ought to be according to the Creation narratives in Gen 1 and 2. I do not dispute that these narratives can be interpreted as Noort suggests, but I cannot agree with his argument that this was the intent of the ancient priestly and Yahwist writers.

The term כנגדו (the adverb usually "opposite/in front" in Scripture), with the conjunction כ "as," appears only twice in Scripture, in Gen 2:18 and 2:20, and hence we have no basis of comparison to ascertain its exact meaning. In fact, we find different interpretations of this phrase. $\mathrm{Tg}$. Onq. translates it literally: סמך כקבליה "help opposite/against." Tg. Ps.-J., adding some words for a better understanding, interprets it as אתא דתהי סמיך כקבליה "a woman which will be a help against you," but translates literally the ambiguous כנגדו סנדו The KJV and NIV use "a helper suitable for him," whereas the NRSV gives "a helper as his partner." The LXX and the Greek Tobit 8:6, which record the text of Gen 2:18, use the preposition $\varkappa \alpha \tau \dot{\alpha}$, which has an almost infinite number of meanings, ${ }^{13}$ the Lxx uses the accusative case, and Tobit the dative. These two Greek texts differ in interpreting the phrase עזר כנגדו, which occurs in Gen 2:18 and 2:20. The LXX uses in 2:18 the adverb $x \alpha \tau \dot{\alpha}$ and the accusative, but in 2:20 the dative with the addition of öpolos "like to him." Tobit, which combines Gen 2:18 and 2:20 in one verse, also interprets the same phrase differently at its first and

Phyllis Trible, God and the Rhetoric of Sexuality (Philadelphia: Fortress Press, 1978) 100, who writes that "the relationship of this couple [created by God from the same bone and flesh] is one of mutuality and equality," and agrees with Trible's statement. As I shall demonstrate, the Bible's attitude towards women is not negative, and woman's function as man's helper does not imply an inferior status. On the other hand, Tikva Frymer-Kensky, In the Wake of the Goddesses: Women, Culture and the Biblical Transformation of Pagan Myth (New York: Ballantine, 1992) at 119 writes that in "the position of women in society as expressed in the laws and in the narratives, we see a situation in which women are clearly subordinate to the men in the household."

Ed Noort, "The Creation of Man and Woman in Biblical and Ancient Near Eastern Traditions," in The Creation of Man and Woman: Interpretation of the Biblical Narratives in Jewish and Christian Traditions (ed. Gerard P. Luttikhuizen; Leiden: Brill, 2000) 1-18 at 12.

13 Including "down, by, according to" when followed by an accusative noun; and "down from, beneath, against" when followed by a genitive noun. 
second occurrences. The KJV translates, "Thou madest Adam, and gavest him Eve his wife for an helper and stay: of them came mankind: thou hast said, It is not good that man should be alone; let us make unto him an aid like unto himself," adding "like unto himself" in the second instance. John William Wevers translates/interprets the Greek translation in 2:18 as "according what is before him" and in 2:20 as "similar to him."14 This is simply a stylistic philological adjustment, appropriate for distinguishing God's perception in v. 18 from Adam's in v. 20 (if indeed v. 20 refers to him). We should not assume, however, that the author of these two verses, in using the same term (unique in Scripture) in both, intended it to have different meanings in two adjacent verses relating to the same subject (man). Therefore, just as the helper "for" or "like" the man is compared in 2:20 to female animals, for which there are divisions of tasks but no differences in rank, the same applies in 2:18, which represents the divine view of human gender.

J.T.A.G.M. van Ruiten analyses this problem in depth and demonstrates that according to the LXx, עזר כנגדו would mean "a helper matching him," and according to Tobit, "a helper fit for him.."15 Having analysed and compared the Creation narratives in Jubilees, the Sibylline Oracles, and 2 Enoch (Slavonic Apocalypse), he states, "The investigation has shown that the reception of the narrative of the creation of man and woman in Early Jewish literature has been diverse."16 L. Teugels translates כנגדו as "corresponding to him," which makes it impossible to deduce from this phrase that man and woman have different ranks. ${ }^{17}$ Westermann's interpretation is most auspicious: "The phrase 'a helper for him' refers neither to the sexual nature of woman (so Augustine) nor to the help which she could offer to the farmer. Any such limitation destroys the meaning of the passage. What it means is the personal community of man and woman in the broadest sense, bodily and spiritual community." Regarding the relationship between man and woman, he concludes that "the narrative in Gen 2 reflects a stage in civilization which was aware of the great importance of the role of a woman in the existence of humankind."18

14 John William Wevers, Notes on the Greek Text of Genesis (Atlanta, GA: Scholars Press, 1993).

15 J.T.A.G.M. van Ruiten, "The Creation of Man and Woman in Early Jewish Literature," in The Creation of Man and Woman: Interpretation of the Biblical Narratives in Jewish and Christian Traditions (ed. Gerard P. Luttikhuizen; Leiden: Brill, 2000) 34-62 at 36-39.

16 Ibid., 61.

17 L. Teugels, "The Creation of the Human in Rabbinic Interpretation," in The Creation of Man and Woman: Interpretation of the Biblical Narratives in Jewish and Christian Traditions (ed. Gerard P. Luttikhuizen; Leiden: Brill, 2000) 107-27 at 120. Teugels claims in note 40 that his "translation is more literal and fits better with the midrashic interpretation in b. Yeb.," cited below.

18 Westermann, Genesis $1-11,232$. See the next paragraph for a similar rabbinic opinion. 
The rabbis were likewise aware of the ambiguity of כנגדו, and indeed interpreted it in a double sense in b. Yeb. 63a: זכה עוזרתו לא זכה כנגדו "If he [the husband] deserves, she [the wife] will be his help; if he does not deserve, she will be against him." In fact, they interpret כנגדו as "opposite/against" in the literal sense of opposition. It is noteworthy that the rabbis, who used biblical verses or phrases in far-fetched ways to create midrashim justifying woman's inferiority or wickedness, do not use the phrase עזר כנגדו to substantiate their theory; ${ }^{19}$ this demonstrates that, in their learned opinion, the purpose of woman's creation and her function as helper do not, in themselves, indicate inequality between man and woman or woman's subservient status, as some scholars argue. Indeed, the pragmatic rabbis appreciated woman's importance for man's benefit, understanding woman's function as man's helper. We can observe this in an aggadah in b. Yeb. 63a, in which Elijah elucidates to Rabbi Jose that woman's helpfulness to man consists in the transformation of raw substances brought home by him, such as grain and flax, into useful items. The rabbis do not conjecture about the abstract issue of woman's inferiority, reflecting instead on the relationship between man and woman in practice and on her function as man's helper. From other rabbinic halakhot and deliberations we can again deduce a concept of equality in their interpretation of the woman's function as a helper. M. Ket. 5:5 enumerates the wife's obligatory functions for her husband, but if she brought maiden slaves with her in her dowry, they can do the work for her, and she can sit on her throne, doing nothing. ${ }^{20}$ Hence, her functions for or services to her husband are not perceived as low-grade domestic, but as equivalent and complementary to the husband's obligations for his wife's benefit, as we read in m. Ket. 4:4, supplemented in b. Ket. $47 \mathrm{~b}^{21}$ and edited by Maimonides in Mishne Torah Hil. Ishut 12:1-2. ${ }^{22}$

19 For example, see a midrash by Rabbi Joshua of Sakhnin on the term ויבן in Gen 2:22 (p. 42).

20 A disputing Rabbi contends that she must at least work with wool, because idleness breeds libidinousness. B. Ket. 61a offers a different qualification of the wife's task: she must fill his cup with wine, prepare his bed, and wash his face, hands, and feet, because these are intimate functions that only a wife may accomplish for her husband.

21 The mishna enumerates the husband's obligations towards his wife, and is complemented in the Gemara, which justifies each of his obligations by the privileges he enjoys in marrying her. We observe again the rabbinic equalization of the mutual obligations between husband and wife. Exod 21:10, the foundation of these rabbinic ordinances, is quoted and deliberated upon.

22 We read that at his wedding, the husband will incur ten obligations to his wife and will obtain ten entitlements; the Torah is the source of three, and the other seven are rabbinic stipulations. 


\subsubsection{Implications of Man's Prior Creation}

Scholars have considered the difference between Gen 1:27, which announces the simultaneous creation of man and woman, and Gen 2:20-22, which records woman's later creation as a divine afterthought, thus arguably demonstrating her inferiority. Various interpretations are employed to repudiate this interpretation and offer other conclusions, among them the contrary deduction that only after the creation of woman was the divine creation finally accomplished, making her the pinnacle of creation. ${ }^{23}$ Noort writes that Gen 1:27 "aims at the credo that the separation in male and female belongs to creation from the beginning. There is no priority." He disputes the rabbinic midrash of Gen. Rab. parsha 8:1 that man was initially created androgynous, ${ }^{24}$ but at the same time declares, "it is unlikely that the priestly writer [of Gen 1] should correct the older story of creation [of Gen 2] in aiming at an equal position for males and females." 25 Thus, like the traditional commentators, Noort does not perceive a contrast between the Creation narratives in Gen 1 and Gen $2,{ }^{26}$ although other scholars do not accept this explanation. He alleges that the male and female are differentiated in Gen 1:27 "because it foreshadows the blessing of fertility of Gen 1:28." 27 It seems to me that there is some contradiction between Noort's comments on Gen 1 and 2 and the concluding sentence of his study. Debating

23 See on p. 44 the rabbinic midrash in b. Yeb. 63a on the phrase זכר ונקבה בראם (Gen 5:2).

24 Noort, "The Creation," 8-9. We read in Gen. Rab. parsha 8:1 Rabbi Jeremiah's statement that when God created the first man, He created him an androgyny, that being the meaning of the phrase זכר ונקבה ברא אתם "male and female he created them" (Gen 1:27); Rabbi Samuel expanded on this, explaining the mechanism: God created Adam the First with two faces, and then sawed him, and made of him two backs, one to one side and one to the other side, and cut them in two parts (literally) shoulders, one to one side and the other to another side.

25 Ibid., 7. The common opinion that the later P version is the source of Gen 1 has lately been questioned by computer scientists from Bar Ilan University in Ramat Gan who created a program that detects joint or distinct sources of given texts, and have concluded that Gen 1 is not a priestly document. A possible validation of this allegation might greatly influence scholarly conjectures regarding the two creation narratives.

26 Ibid., 3: "In the final text, we have the sequence that man is created first as male and female and afterwards a detailed account tells us man is created first and woman after him." Noort's explanation concords exactly with the traditional elucidation expressed in Rashi's comment on Gen 1:27: "Here, he informs you that both [man and woman] were created on the sixth day, and did not explain to you how their creation proceeded; that, he explained in another place [in Chapter 2]." Ibid., 8 . 
Carol Meyers, ${ }^{28}$ he says of the differentiation between male and female in the payments for the commutation of vows in Lev 27:2-7 that "it must be that the Priestly Code [Gen 1] is written in a social context where a male is worth more. ${ }^{29}$ Hence, if I understand him correctly, even the priestly Creation narrative in Gen 1 considers the woman inferior to man. On the other hand, he concludes the chapter by stating that "In the real world of the narrator man and woman are not equal. The narrator of the poetic scene of Gen 2 shows, however, that this [inequality] is not the original plan of Yahwe Elohim." ${ }^{30}$ Here Noort seems to be asserting that the texts of Gen 1 and 2 indicate that man and woman are equal.

Some scholars have attempted to dismiss the suggested significance of man's prior creation by appealing to the midrash of Gen. Rab. 8:1, cited above, which argues for an androgynous creation (as recorded in Gen 1:27), subsequently divided by God into man and woman (as recorded in Gen 2:21-22); thus, they assert a simultaneous creation of both genders. ${ }^{31}$ However, this interpretation does not resolve the claim that man holds favoured status because of his prior creation, if indeed this implies superiority over the later-created woman. It solves the apparent contradiction between the statements in Gen 1:27 that both man and woman were created together, and the divine pronouncement in 2:18 indicating the woman's later creation, but not the claim that man was not created prior to woman. In fact, according to the midrash, the man was in essence created first, and the woman was only subsequently shaped from him. Further, because this is only one of the rabbis' various imaginative explanations of the apparently simultaneous creation of man and woman, it cannot serve as evidence for an interpretation of the scriptural narrative, which implies that woman was a later creation.

I dispute Susan Niditch's assertion that the rabbinic midrash of the androgynous creation was intended to resolve "the tension between male and female, the tempted and the temptress, by insisting that maleness and femaleness

28 Carol L. Meyers, "Gender roles and Genesis 3:16 revisited," in The Word of the Lord Shall Go Forth; Essays in Honor of David Noel Freedman in Celebration of His Sixtieth Birthday (eds. Carol L. Meyers and M. O'Connor, Winona Lake, IN: Eisenbrauns, 1983) 337-354, at 346 argues that the woman's "pregnancy and parturition together [cited in Gen 3: 16], along with the subsequent nurturing, constitute the reproductive function of women in society."

29 Noort, "The Creation," 7.

30 Ibid., 18.

31 Trible, God and the Rhetoric of Sexuality at 140 offers a similar but different concept. Before the creation of the woman, the divine earth creature was still sexually undifferentiated; it was "not androgynous or bisexual, since sexuality was still to be created." 
were characteristic of the first man himself." ${ }^{32}$ Rather it is evident from the midrash that its purpose is to solve the contradiction between the phrase (Gen 5:2) in the plural, "He created them male and female," and בצלם אלהים ברא את וכרה (Gen 1:27) "in the image of God created he him" (KJV translation), in the singular. ${ }^{33}$ Rabbi Jeremiah states that the first creation was androgynous, and this is the meaning of the verse in Gen $5: 2 .^{34}$ In $b$. Erub. 18a Rabbi Abuhu points explicitly to the contradiction between the contents of the two verses and he resolves it by advancing the notion that initially God intended to create two [humans], but then created only one.

In view of the solution proffered in Gen R., a further question was raised regarding the contradiction between the claim of an androgynous creation and subsequent separation of two faces and two backs, as explained by Rabbi Samuel, and the assertion of Gen 2:21-22 that the woman was created from Adam's rib. ${ }^{35}$ This query is solved by a reply that the term צלע in Gen 2:22, commonly translated as "rib," also has other meanings, such as "side/along," as בצלע ההר for example צלע המשכן "side of the tabernacle" in Exod 36:31 and "along the hillside" in 2 Sam 16:13. Thus, the term צלע הלע in Gen 2:21 is compatible with the separation of the androgynous creation. ${ }^{36}$ These deliberations clearly indicate the motive and scope of these midrashim, namely the resolution of

Susan Niditch, "The Cosmic Adam: Man as Mediator in Rabbinic Literature," JSJ 34, 2 (1983): $137-46$ at $140-41$.

33 One may wonder why the midrash of $b$. Erub. queried the apparent contradiction between the plural of Gen 5:2 and the singular in Gen 1:27, since we encounter both plural and singular in the same verse Gen 1:27:בצלם אלהים ברא אתו זכר ונקבה ברא אתם (literally) in God's image he created "him" male and female he created "them." The question is even more acute, since in the dictum of Rabbi Abuhu, quoted in b. Ber. 61a, he cites the contradiction between the use of plural in Gen 5:2 and of singular in Gen 9:6; the answer is identical in both sources. Is it a deliberate choice, which has some hidden motive, such as the issue of whether only man or both man and woman were created in God's image, or just a random choice without any underlying intentions? This is, however, an issue we cannot deliberate upon here. As it seems to me, the text of Gen 9:6 in singular form must be interpreted as referring to humankind; hence, it should not be perceived as really expressing a singular creation, but rather indicating that both man and woman were created in God's image.

34 See note 24.

35 See also Teugels, "Creation of the Human," 112-13 on this issue.

36 Victor P. Hamilton, The Book of Genesis Chapters 1-17 (Grand Rapids, MI: Eerdmans, 1990) 178, suggests translating צלע as "side," supporting his argument with further appropriate quotations. He disputes the idea of an androgynous creation, arguing that "such teaching goes beyond the statements of Genesis," since the text states that Eve was formed from the side of Adam. 
the obvious contradictions between the biblical narratives about the woman's creation; the philosophical cogitations presumed by Niditch were not on the minds of the authors and redactors of these deliberations, or indeed of the subsequent midrashim, asserting that God initially created Adam as an amorphous entity lying from one end of the world to the other, and describing Adam's enormous proportions-from East to West, from North to South, filling the entire space of the world. The traditional commentators connect these midrashim to the preceding as other solutions to the apparent contradiction between humankind's creation as androgynous, subsequently separated, and the biblical assertion that woman was created from man's rib.

In conclusion, I permit myself to remark that we are obviously justified in interpreting ancient writings in accordance with our contemporary thoughts, but to impose modern views on ancient writers is inappropriate. Niditch's claim that the author of this midrash intended to address a tension between the sexes is untenable for two reasons. First, such tension is a modern concept, inconceivable in the society in which the author lived, since the overwhelmingly dominant position held by men excluded gender-based tension between husband and wife. Second, the authors' and redactors' precisely targeted use of the midrashim indicates their intent, as they understood it. Thus, there is no way to impose on these midrashim a philosophical background of gender politics.

To conclude the discussion of woman's later creation: in my opinion, the simultaneous creation of woman does not indicate equality, nor does her later creation imply inferiority. Other circumstances may influence such conjectures. According to the biblical narrative, the creation of woman is prompted by God's own conclusion that she was indeed missing in his previous creation of man. Further, she is created personally by God-not by intermediate powers such as angels or other messengers, which might hint at an inferior rank of creation. ${ }^{37}$ Woman's later creation may instead denote her significance: without her, God's creation was not fully and perfectly accomplished. ${ }^{38}$ Further,

37 We see the consideration and significance given to God's "personal" intervention in the rabbinic literature in Mek. Bo, Mas. D'Piska, parsha 7 emphasizing in Exod 12:12 God's personal intervention in punishing the Egyptians, and conversely, in Exod 33:3, God's ceasing to escort the Israelites because of their sin with the Golden Calf. Genesis/בראשית: The Traditional Hebrew Text with the New JPS Translation, commentary by Nahum M. Sarna (Philadelphia: Jewish Publication Society, 1989) at 21 draws attention to the fact that whereas "the creation of man is told briefly, in a single verse, the creation of woman is described in six verses," which underlines the significance of the woman's creation.

38 Thomas L. Brodie, Genesis as Dialogue: A Literary, Historical, and Theological Commentary (Oxford: Oxford University Press, 2001) 141, writes: "Human aloneness leads God to say- 
there is no doubt that according to the Creation narrative the creation of humans constitutes the pinnacle of God's creation, to "fill the earth and subdue it" - to rule over all that was created before. This paradigm and the sequence of the ascending order of creation demonstrate that the latest creation was the most important. ${ }^{39}$ Thus, it is illogical to argue that woman is inferior because of her later creation. It seems to me that scholarly efforts to minimize the significance of man's prior creation were intended to debunk Paul's justification of his decree that woman must be submissive because of her later creation: "For Adam was formed first, then Eve" (1 Tim 2:13).

\subsubsection{The Creation of Woman from Man (Gen 2:21-24)}

The Hebrew תרדמה in Gen 2:21-24 is translated by the KJV and NIV as "deep sleep"; the LXX goes a step further, translating it as हैं $\sigma \tau \alpha \sigma \iota \varsigma$ "trance." Tg. Neof. and Tg. Ps.J. also interpret it as שינתא עמיקתא “deep sleep," but the latter adds to the end of the verse the exact identification of the rib: "it [was] the thirteenth rib of the right side." Both ancient commentators and modern scholars have probed why Adam had to be sleeping during the creation of the woman. The JPS Commentary suggests that the sleep had the "dual function of rendering the man insensible to the pain of the surgery, and oblivious to God at work." ${ }^{40}$ I do not find this explanation satisfactory; if the reader believes that God can create the entire world and, specifically, a woman from one of man's ribs, then he could have done so without causing pain to Adam. ${ }^{41}$ As we shall

for the first time - that something 'is not good' (Gen 2:18)." Brodie further notes that the woman is "the high point of creation." Hamilton, The Book of Genesis, 177, calls our attention to the fact that, in contrast to the Israelite Creation narrative, "None of Israel's neighbours had a tradition involving a separate account of the creation of the female."

See Swidler, Biblical Affirmations, at 76 for a more extended treatise on this issue, concluding that "prior creation indicates not superiority but inferiority." Joseph Blenkinsopp, Creation, Un-Creation, Re-Creation: A Discursive Commentary on Genesis 1-11 (London: $\mathrm{T} \& \mathrm{~T}$ Clark International, 2011) 6o, comments that in the second Creation narrative, in Gen 2, the order of creation is reversed: the "human being is created before the wild animals and birds - and presumably also before aquatic creatures, which are not mentioned." Such deduction would not conflict with our assertion that ancient Israelites believed that mankind was the last creation and its pinnacle. For them, Gen 2 was not a different narrative of the Creation, the basis of Blenkinsopp's deduction, but a detailed supplementary portrayal of the concise narrative given in Gen 1, in which unquestionably humans were the last stage of Creation.

40 Sarna, Genesis/בראשית.

41 Mieke Bal, "Sexuality, Sin and Sorrow; The Emergence of the Female Character (A reading of Genesis 1-3)," in Poetics Today 6, 1-2 (1985) 21-42, at 26, following Trible's theory that man was asexual before the woman's creation, interprets the phrase עזר כנגדו as neutral 
see, the rabbis do not use this expedient to resolve the same question. Modern scholars have argued that "man ought not to be a witness of the work of creation," but Westermann disputes this, arguing that "it is too rational an explanation for this ancient motif." 42 Likewise, Cassuto perceives it as introducing into the biblical passage "a philosophical concept that is completely foreign to it." ${ }^{3}$ B. Sanh. 39a offers a different solution to this conundrum while discussing another aspect of woman's creation from man (paraphrased and condensed): Caesar said to Rabban Gamaliel, "Your God is a thief, since he took a rib from Adam in his sleep." Gamaliel's daughter said to Caesar, "Robbers raided us last night and took from us a silver cup and left us instead a golden cup." Caesar told her, "We would like such a robber to come to us every day," but she replied, "Wasn't it advantageous to Adam the First, from whom one rib was taken, that he was given instead a handmaiden to serve him?" Caesar replied, "I meant to say that God could have taken the rib overtly—not in his sleep." Then she said, "Bring me a plate with raw meat"; they brought it to her, and she put it under her armpit and took it out, saying to him, "Eat it," but he said, "It is repulsive." She said to him, "The same would have happened to Adam; if he had seen the creation process, she would have been loathsome to him."

A similar narrative appears in Abot R. Nat. Recension b, 8, in which Rabbi Joshua is questioned by a woman who accuses God of theft and answers her with a parable in which he compares God's act to the replacement of an earthen brick in a wall with a golden brick. However, although in both narratives the woman is deemed important for the benefit of man, the first compares her to a servant, whereas the second compares her to a precious golden brick. While this distinction may have been deliberate ${ }^{44}$ indicating a different ideological background regarding woman's status, equally these similes may have been

"corresponding to it" instead of in the masculine as it is written. She states further that the man's sleep signifies "the death of the undifferentiated earth creature." Consequently, the woman was created from the amorphous asexual creature, and hence there is no contradiction between the narratives in Gen 1 and 2. The two sexual humans were created only at their separation.

42 Westermann, Genesis 1-11, 230.

43 Cassuto, Commentary on Genesis, 133. See my extended study on the topic of imposing modern thoughts on ancient authors and readers in Paul Heger, Challenges to Conventional Opinions on Qumran and Enoch Issues (STDJ 100; Leiden: Brill, 2011) 103-58, particularly at 104-8.

44 The author uses a downgrading expression, depicting the married woman's status as a לשמשו a maidservant/female slave to serve him." The term is often used in rabbinic literature as a euphemism for sexual relations, but in this context associated with the term שפחה it must be interpreted as maidservant or female slave. 
chosen at random to give logical answers to the posited questions, without any underlying ideological agenda.

It seems to me that the author's emphasis in Gen 2:23 seen in Adam's pronunciation that the woman is "bone of my bones and flesh of my flesh" indicates its significance for the relationship between man and woman, created from his body and thus an integral part of him. ${ }^{45}$ As I will argue below, the phrase (Gen 2:22b) acknowledging that God created the woman from the rib that "he has taken from the man" seems superfluous, since the preceding verse 21 describes the procedure of God taking one of man's ribs and closing up the resulting hole with flesh. The repetition therefore seems to emphasize the author's desire to underscore the significance of Adam's assertion and its legal implications. Thus, women's subordinate legal status is derived from the Creation narrative, while the idea that women are generally inferior to men is derived from an erroneous interpretation of the Fall narrative (as I shall demonstrate in the next chapter), which various subsequent biblical interpreters have exploited to create this negative image of women.

What scholars have generally overlooked or granted too little significance with respect to women's legal status, as implied in the Gen 2 narrative, is woman's creation from man's rib. ${ }^{46}$ Likewise, they do not accord enough importance to Adam's outright statement that the woman is part of him, bone of his bones and flesh of his flesh, and the fact that he names her, ${ }^{47}$ whereas

45 Hamilton, The Book of Genesis, 179, perceives Gen 2:23 as significant because "for the first time in Scripture the words of a human being are recorded in direct discourse." He also suggests that flesh symbolizes weakness and frailty, while bones represents the opposite, the symbol of individual strength, hence the human character. Walter Brueggemann, "Of the Same Flesh and Bone (Gen 2.23a)," CBQ 32 (1970), 532-542, writes that the phrase "my/ your flesh and bone" represents a covenant formula; that is, a reciprocal loyalty between man and woman.

46 Carol A. Newsom and Sharon H. Ringe, eds., The Women's Bible Commentary (Louisville, KY: Westminster John Knox Press, 1998) at 16 state that "Jewish and Christian traditions postdating the Hebrew Bible and a long history of Western scholarship have viewed woman's creation in Genesis 2 as secondary and derivative-evidence of her lower status." My own view, to be substantiated in subsequent chapters, is that woman's dependent legal status is, instead, the consequence of her creation from man.

47 John J. Collins, Genesis 1-4: A Linguistic, Literary, and Theological Commentary (Phillipsburg, NJ: P\&R Publishing, 2006) at 138 writes, "Naming seems also to be an exercise of authority." He deduces this from the fact that Adam, who named the creatures, was given dominion over them (Gen 1:28). Trible, God and the Rhetoric of Sexuality, 99-100, states that Adam did not name the woman in 2:23; instead, he was identifying their commonality in difference. The terms man and woman "convey the respective sexuality of each of them." 
his own name, Adam, was given by God (Gen 2:16). ${ }^{48}$ These details of woman's creation seem to me significant as a guideline for perceiving the biblical point of view on woman's legal status. I suggest that the narrative of the woman's creation, rather than that of the Fall, was the primary basis for woman's subordinate legal status, which developed into submissiveness to her husband, as implied in the Fall narrative. The text of the divine verdict and the woman's specific position, which is to desire her husband and to be ruled by him, would be utterly unreasonable, as I will show, if not for her standing as a part of the man. I would not exclude the possibility that God's announcement to the woman in Gen 3:16 is a later interjection in the Fall narrative, as I shall discuss in Chapter 2.

Gen 2:22, exceptionally, uses the verb בנה, which normally refers to building a house, in contrast to the neutral verbs used elsewhere in the Creation narrative:יצר and ברא, עשה. The traditional Targumim, Tg. Onq. and Tg. Ps.J., usually

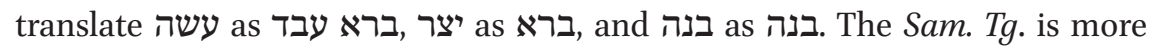
precise, translating יצר in Gen 2:7, 8, and 19 with צור "to form, shape, paint," an expression that emphasizes the specific shaping of man and animals in the relevant biblical contexts, in contrast to the generic, undefined עבד. The LXx

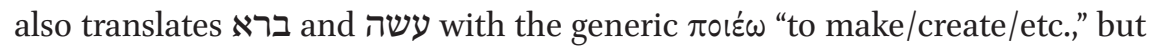
translates יצר with the more specific $\pi \lambda \dot{\alpha} \sigma \sigma \omega$ "to form/mould/shape." The term

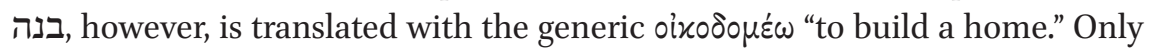
Tg. Neof. makes an exception, translating ברא ,עשה as ברא (with one

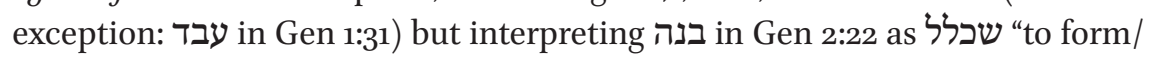
adorn/complete."49 The use of בנה for the woman's creation alone induced the rabbis, the authors of ancient Targumim, traditional commentators, and modern scholars to seek a motive for this exception.

The rabbis, as usual, offer a great array of midrashim explaining this apparent oddity; some are neutral towards women and seem only to relate to the rationale for the term used, while others are inspired by positive or negative preconceptions about the character of women. We read in b. Erub.18b that God built Eve like a granary, which is narrow at its top and wide at its bottom to receive the fruits; so is the woman slim in her upper body and stocky in her lower part to bear a child. B. Ber 61a states, slightly more kindly, that God braided Eve's hair and brought her to Adam, since in some cities by the sea they call a

48 The Lxx here interprets האדם as a proper name, $\tau \hat{\omega} \mathrm{A} \delta \alpha \mu$, instead of the generic $\dot{\alpha}^{2} \nu \rho \omega \pi / \varsigma$ "mankind." See Wevers, Notes on Genesis, on this verse.

49 Marcus Jastrow, A Dictionary of the Targumim, the Talmud Babli and Yerushalmi and the Midrashic Literature (Leipzig, 1903; Jerusalem: Horeb, n.d.); Michael Sokoloff, A Dictionary of Jewish Palestinian Aramaic (Jerusalem: Bar Ilan University, 1990). 
hairdresser binyatta (similar to the Hebrew בנה "to build"). We can assume that the Tg. Neof. interpretation שכלל, quoted above, has an affinity with this and other similar rabbinic midrashim that accentuate God's "personal" effort to make the encounter of man and woman as pleasant and effective as possible, indicating the importance of a harmonious family life.$^{50}$ Further rabbinic midrashim on the term בנה, some favourable to women and others most denigrating, are quoted on pages $42-45$.

The modern but traditionally minded commentator Cassuto generally prefers the favourable rabbinic midrashim and perceives the use of the verb to build as "suited to the theme; just as a builder builds, with the raw materials of stones and dust, an edifice of grace and perfection, so from an ordinary piece of bone and flesh the Lord God fashioned the most comely of his creatures."51 Modern scholars consider the use of "built" a remnant of ancient Near Eastern mythologies, such as the Akkadian and Ugaritic, which used this term to describe how the gods created human beings.

\subsubsection{God's Presentation of Eve to Adam, and His Reaction}

The next phrase, "and he brought her unto the man," is used in rabbinic midrashim to emphasize that God adorned her and acted as her bridal attendant; he led her to the wedding ceremony, as parents lead their daughter to the wedding canopy, according to Jewish custom. We read in Gen. Rab. 18: "he brought her to Adam after adorning her with twenty-four jewels." B. Ber. 61a interprets the phrase "and he brought her unto the man" (v. 22b) as showing that God acted as Adam's best man.

The odd beginning of Gen 2:23 has inspired many interpretations aimed at resolving its peculiarity. Its literal translation, "this time a bone from my bones and flesh from my flesh," sounds awkward; it does not have a verb, and it is not clear who or what is the subject of the demonstrative pronoun "this." The $\mathrm{NIV} / \mathrm{KJV}$ translation, "This is now bone of my bones," suggests that "this" refers to the woman, but the adverb "now" raises a further question, since it seems to allude to some unknown thing that occurred before. The LXX, as Wevers comments, translates "this" in neutral form, agreeing with "bones" (a neutral noun), rather than in feminine form, as one would expect if it refers to the woman. Wevers conjectures that the LXX "probably means 'now' in the sense of 'at last, finally' ";52 this raises the same problem as the NIV translation, which

\footnotetext{
50 Newsom and Ringe, Women's Bible Commentary, 16, state: "The conjugal couple is the foundation of social and cultural relationships for the writers of Genesis."

$5^{1}$ Cassuto, Commentary on Genesis, 135.

$5^{2}$ Wevers, Notes on Genesis.
} 
probably follows the LXx. The JPS translation gives "This one at last," relating the pronoun to the woman, and explains that Adam is contrasting the woman with the animals (Gen 2:20), who already have mates, ${ }^{53}$ as Wevers also suggests. However, two sentences divide the naming of the animals from Adam's exclamation (Gen 2:23), and a great many events take place, including Adam's deep sleep and the surgical operation; this interpretation, therefore, does not offer an adequate solution. Cassuto relates the pronoun "This" to the woman and explains the sense as follows: "this creature, this time [that is, at last], is in truth a helper corresponding to me. ${ }^{54} \mathrm{He}$ connects Adam's exclamation to Gen 2:20, arguing that whereas in v. 20 Adam did not find a helper among the animals, now he proclaims that he has finally found a suitable helper.

This last interpretation follows rabbinic midrashim. We read in Abot R. Nat. Recension b, Chapter 8 (paraphrased): Adam complained to God, "Master of the World, for all the creatures you created in the world you created a mate, yet I don't have a mate" (see Gen 2:20); hence, when Adam saw Eve, he said, "This is my mate." Gen. Rab. 18 parsha 4 offers another explanation for what happened before, namely that God first brought the woman to Adam right after her creation, but seeing her full of slime and blood repulsed Adam, so God took her back and created her anew; this would explain why Adam says that "this time" he is happy. Commentators and scholars agree that Adam's announcement indicates his happiness at having a mate, describing his utterance as, for example, "a cry of ecstatic elation," "a jubilant welcome," and "enthusiasm and heart's joy" "55 Since many midrashim, commentators, and scholars interpret the entire verse as a whole, I will discuss them after elucidating some textual problems.

Some rabbinic midrashim interpret the phrase "This time" differently, simply as "time," intending to emphasize "this time and no more." Abot R. Nat. Recension b, Chapter 8, states: "This time was the woman created from 'man,' but from now on 'a man' marries the daughter of his friend and is obligated to fulfill the precept of procreation; another interpretation is that this time

53 Sarna, Genesis/בראשית.

54 Cassuto, Commentary on Genesis, 135.

55 On this foundation, it seems, John Milton, in Paradise Lost, changed the biblical story, such that when Adam finds out that Eve has broken God's commandment and is going to die, he decides of his own will to eat the fruit also, and die with her, rather than survive without her-thereby forsaking Paradise and eternal happiness for himself and the world for love of Eve. Milton's Adam uses the biblical language of Gen 2:23: "The link of Nature draw me: flesh of flesh,/ Bone of my bone thou art, and from thy state/ Mine never shall be parted, bliss or woe" (Paradise Lost, Book VIII). 
God was the best man, but from now on a man has to provide a best man for himself." Tg. Ps. J. interprets as follows: "The man said: this time and no more will the woman be created from 'a man' as this one." Tg. Neof. interprets this verse similarly, using the Aramaic term גבר instead of In In I. Ps. J. We observe that both translators/interpreters distinguish between "Adam," the first subject, and "man" from whom woman was created in the second part of the verse; this indicates that Adam after Eve's creation is not the same entity as beforehand. Thus, they emphasize that woman was created from man, like the

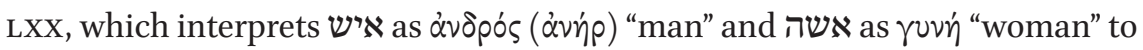
emphasize the different genders. Both Westermann and Cassuto note the affinity of the expression that associates bones and flesh with other similar biblical expressions, as for example in Gen 29:14, that imply a permanent relationship between man and woman. ${ }^{56}$ The traditional commentator Rashbam interprets the verse as follows: "Only this time the woman is a bone of my bones, but from now on it is not so, but (the opposite:) the man comes forth from the woman." Ibn Ezra links this verse to v. 20 and to Adam's complaint about not having a suitable helper: "After [the woman was brought to Adam,] he said, "This time I have found a suitable helper like myself,' since she was taken from him."

Adam says that the woman is bone of his bones and flesh of his flesh, but how does he know this? He was in a deep sleep when God carried out his surgery and closed up the hole with flesh, as is emphasized in Gen 2:21. ${ }^{57}$ Perhaps he sees that she is similar to him, more similar than any of the other animals that God brought to him for naming, but he cannot know that she was taken from him. Westermann writes that one should not understand the creation of the woman from the rib of man "as a description of an actual event accessible to us"; he likewise perceives the creation of Adam from earth as a transmission of ancient mythologies in which humans were created from different materials. ${ }^{58}$ Behind man's creation from earth lies the ancient technique of producing human figures out of clay; woman's creation from man's body, he argues, is meant to explain how man and woman belong together. I would suggest, by contrast, that the purpose of this narrative is aetiological: it is intended to justify woman's lack of individual legal status by explaining that she is part of

\footnotetext{
56 Westermann, Genesis 1-11, 232; Cassuto, Commentary on Genesis, 135-6.

57 The NIV, traditional commentators, and the LXx translate תחתנה as "instead of it," as in Gen 4:25, 22:13, 30:15, and 44:4; Exod 21:23-27, 21:36-37; Lev 16:32, 24:118, and 24:10; Num 3:12, 3:41, 3:45, 8:16, and 8:18; and many other instances. See discussion of Gen 2:21 above.

58 Westermann, Genesis 1-11, 230.
} 
man. ${ }^{59}$ We observe in a collection of English laws published in 1632, The Lawes Resolutions of Womens Rights, a vivid concrete portrayal of how a woman loses her own personality when she marries, an idea deduced from Gen 2:23. We read there:

In this consolidation which we call wedlock is a locking together. It is true, that man and wife are one person (bone of my bones, and flesh of my flesh) but understand in what manner. When a small brooke or a little river incorporateth with Rhodanus, Humber, or the Thames, the poor rivulet looseth her name... A woman as soon as she is married, is called covert...that is, veiled, as it were, clouded and overshadowed; she hath lost her streame. I may more truly, farre away, say to a married woman, Her new self is her superior; her companion, her master ...60

The last element of the verse, Adam's naming of the woman, is tightly linked to her creation from man; translators, commentators, and scholars therefore interpret it differently according to their attitudes regarding the resulting relationship between man and woman. Nahum Sarna, in the JPS commentary on Genesis, asserts that the text voices the social reality of the Ancient Near East that "naming implies authority," and hence a subordinate status for the woman; on the other hand, he asserts that "in naming her "ishah, he simultaneously names himself... ish...thus he discovers his own manhood and fulfillment only when he faces the woman, the human being who is his partner in life."

59 Frymer-Kensky, In the Wake of the Goddesses, 120, writes, "The social system reflected in the Bible did not originate in Israel, nor is it substantially different in the Bible than elsewhere in the Ancient Near East." This is true to a certain extent, but the Israelites also made crucial changes to many laws in general, and to laws relating to women in particular that demonstrate a fundamentally different ethical approach to human relations. For example, men and women were equal with respect to Scripture's prohibition on spilling blood, a principle of utmost significance that differed from parallel rules in the surrounding cultures.

6o The Lawes Resolutions of Womens Rights. A Methodical Collection of Such Statutes and Customes, with the Cases, Opinions, Arguments and Points of Learning in the Law, as do Properly Concerne Women, quoted in Howard Zinn, A People's History of the United States (New York: Harper Perennial, 1980; reprint, 2009) 106. Martha T. Roth, "Gender and Law: A Case Study from Ancient Mesopotamia," in Gender and Law in the Hebrew Bible and the Ancient Near East (ed. Bernard M. Levinson et al.; Sheffield: Sheffield Academic Press, 1998) 173-84, at 181 quotes William Blackstone, Commentaries on the Laws of England. I. Of the Rights of Persons (1765) (Chicago: University of Chicago Press, 1979) at 430: "By marriage, the husband and wife are one person in law." 
The assumption that ish and ishah are personal nouns is the basis of Sarna's argument, but these nouns seem to me to be generic. Furthermore, there appears to be an inconsistency between the degrading consequences of man's authority to name the woman and his assertion of equality in naming her ishah. ${ }^{61}$ Westermann, in contrast, perceives that "the narrative in Gen 2 reflects a stage in civilization which was aware of the great importance of the role of woman in the existence of humankind." ${ }^{2}$ However, he attempts to resolve the contradiction with Adam's naming of the woman, which implies his authority over her, by arguing that "the name aetiology of v. 23b, though certainly belonging to the narrative and firmly fixed in it, is a secondary trait, not a goal" of the narrative. ${ }^{63}$ Cassuto, citing a traditional commentator, perceives the similarity of the names of man and woman (אשה איש and to mean "she is worthy of being called by the same name as myself." ${ }^{4}$ The repetition of זי מאיש לקחה זאת in the last phrase of the verse כי זהת omits it; Tg. Ps. J. and Tg. Neof. emphasize the aetiology or justification of the woman's name, אשה, and at the same time validate the repetition of the pronoun זאת. They add in their interpretations that "it is appropriate" for her to be called "woman" because she was created from man.

Adam's declaration indicates that the woman is part of him, being "flesh of my flesh." The translation of Tg. Onq "since she was taken מבעלה from her husband," emphasizes her nature as part of her husband and thus establishes it as the foundation of biblical and rabbinic legislation regarding women's legal status. A midrash in b. Nid. $31 \mathrm{~b}$ acknowledges this as representing the reality of life, stating that a man courts a woman, rather than the other way around, because he is looking for what he has lost, namely his lost rib from which the woman was created. In fact, Gen 2:23 emphasizes this through Adam's pronouncement, which changes the appellation of the same subject within the one verse. At the beginning, the speaker is called האדם Adam - still a generic name, denoting humankind-whereas at the end of the verse he calls himself איש "man," emphasizing the reality that woman was created from man, and is part of him. ${ }^{65}$ Gen 2:24, which explicitly refers to the preceding verse through the use of the adverb על כן "therefore" by the narrator (God), seems to conflict logically with Adam's utterance in v. 23. If the woman was taken from him, the man, and is bone of his bones and flesh of his flesh, one would expect that

\footnotetext{
61 Sarna, Genesis/בראשית, 23.

62 Westermann, Genesis 1-11, 232.

63 Ibid.

64 Cassuto, Commentary on Genesis, 134.

65 On this issue see Swidler, Biblical Affirmations, 77.
} 
through their reunification (i.e., marriage) and redress of the encroachment upon his body, the woman should cling to him to become again "one flesh," not the opposite, as is written:ודבק באשתו "he will cling to his wife."66 It seems that the Targumim were aware of this issue and attempted to resolve it as follows: Tg. Onq. interprets it thus: "therefore a man will leave the dwelling of his father and mother and adhere to his wife, and they will become one flesh," suggesting that the core and main emphasis of this circumstance is the man's leaving his parents' dwelling in order to join his wife in creating a new family. ${ }^{67} \mathrm{Tg}$. Ps. $J$. has a similar interpretation: "Therefore, a man will separate from his father's and mother's dwelling and will associate/unite with his wife, and both will be one flesh." Tg. Neof. uses two different terms in its interpretation, but in essence corresponds with the interpretation of Tg. Ps.J. All three Targumim, that is, interpret the first part of Gen 2:24 as relating to the man's leaving the parental home in which he lived, as was the custom, ${ }^{68}$ and creating a new home. ${ }^{69}$ In fact, it is plausible that the narrator intended to emphasize the man's leaving his family—considered to be עצמי ובשרי his "bone and flesh," the common

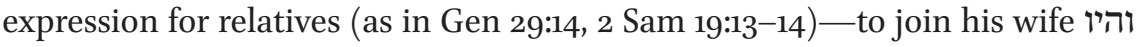
"and become one flesh with her instead."

The addition of "and both will be one flesh" in Tg. Ps.J, Tg. Neof. and the Samaritan Bible seems superfluous, since in the MT, "both" is implicit from the context. The NIV translates "and they become one flesh." English grammar requires "they," but Hebrew grammar does not; the authors/redactors of these texts must therefore have intended readers to infer some specific connotation, but I can envisage more than one possibility. It is plausible that the additional emphasis on the union of male and female refers to their concrete sexual union, implicit in God's first blessing of the primary couple and his command to them to multiply (Gen 1:28). This interpretation is supported by Sam. Tg.'s translation of the biblical term ויתעלץ באתתה as "he will enjoy with his wife," as in 1 Sam 2:1: עלץ לבי "My heart rejoices." It seems to me that both the Samaritan

66 The feminist scholar Mieke Bal, "Sexuality," 29 states indeed that "it is man who will search for the unity rather than the woman."

67 Tg. Onq. uses the original Hebrew דבק "stick/cling/adhere/hold fast," which appears just once more in Scripture in relation to married women (in 1 Kgs 11:2, describing Solomon's adherence to foreign women), translated as "hold fast."

68 When Terah left Ur to go to Canaan, he took with him his son Abram and his grandson Lot (Gen 11:31). Reading Gen 37, one has the impression that Jacob's sons lived together in his household, and Scripture indicates that when Judah intended to marry, he left his brothers (Gen 38:1).

69 Cassuto, Commentary on Genesis, 137, similarly writes that "whilst a man is single, he forms part of his father's family, but when he takes a wife he founds a new family." 
text and Sam. Tg. unequivocally and explicitly accentuate sexual desire and joy והיה מ to express this reality, and Sam. Tg. translates accordingly. The LXx translates oi dvo "the two," as also appears in the Peshitta and Vg. Rashi, for example, also associates the phrase with sexual intercourse, explaining that "the child is created by both, and there their flesh becomes one." Thus Rashi, too, links becoming one flesh to the divine command to multiply in Gen 1:28, which is accomplished by means of concrete sexual activity; it is the child who becomes the one body of his two parents-not, as is commonly understood, the couple themselves. On the other hand, one cannot exclude the possibility that the authors of Tg. Ps. J and Tg. Neof. intended, by adding "both," to emphasize the equality of husband and wife as two entities, male and female, that become one, without establishing the precise aspect and extent of this equality; I discuss this subtle issue later in the chapter.

\subsubsection{Scholarly Opinions and Interpretations}

Thomas Brodie offers a most positive portrayal of woman in terms of her creation from man's rib, stating that "the creation of woman from man does not imply subordination"; rather, she is "equal to man." ${ }^{70} \mathrm{He}$ supports this assertion by stating, for example, that they are "appropriate co-workers" (Gen 1:28); that "God describes both man and woman as very good" (Gen 1:31); and that marriage "is essentially positive and joyful" (Gen $2: 23-24) .{ }^{71}$ To reconcile his assertion with its logical opposite, that man will rule over woman (Gen 3:16), he states that "inequality will come only with sin."72 However, he does not explain why woman was punished with subordination to man as a result of the sin of transgressing God's prohibition, which God attributes to Adam, not to her (Gen 3:17), as I shall argue in the next chapter. Does he follow the conventional interpretation that the woman is the main guilty party in the Fall narrative, and thus loses her original equality with man because of her sin? In his further consideration of the Fall narrative as the first sin, however, Brodie quotes Paul's statement that "sin came into the world through one man, and death came through sin" (Rom 5:12). ${ }^{73}$ Though this mention of "man" could be perceived as relating to a human, male or female, as in the original Greek $\alpha \nu \theta \rho \dot{\omega} \pi \circ \varsigma_{\text {, }}$

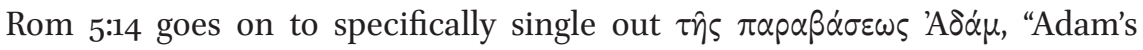

\footnotetext{
70 Brodie, Genesis as Dialogue, 141.

71 Ibid.

72 Ibid.

73 Ibid., 145 .
} 
transgressions" (KJV). Here, then, Paul perceives man, not woman, as the main sinner; the woman is, at the very most, equally responsible.

Cassuto perceives the creation of woman from man as underlining "the affinity between the man and his spouse." Further, comparing man's creation from dust (Gen 2:7) and his return to dust (Gen 3:19) with woman's return to man in marriage, since she was taken from him, leads Cassuto to conclude that the woman must associate constantly with the man. ${ }^{74}$ This opinion does not relate to the legal and practical relationship between woman and man as a result of her being taken from him, however, but only to a doctrinal issue.

Sarna sees in the symbolic creation of woman from man's rib an explanation of "the mystery of the intimacy between husband and wife"; it "connotes physical union and signifies that she is a companion and partner, ever at his side." ${ }^{75}$ He does not perceive any disadvantage to the woman due to being part of the man's body. He writes of Gen 3:16, which states that man shall rule over woman, that "It is quite clear from the description of woman in 2:18, 23 that the ideal situation, which hitherto existed, was the absolute equality of sexes. The new state of male dominance is regarded as an aspect of the deterioration in the human condition that resulted from defiance of the divine will." 76 This interpretation, which disregards the significance of woman's being part of man, has many drawbacks. The term "helper," used to describe the woman in Gen 2:18, has been perceived, rightly or wrongly, as indicating her subservient status, and her later creation as an additional sign that she takes second place to man; ${ }^{77}$ Sarna's notion of equality at the time of Creation, therefore, seems not to be unequivocally based on the biblical description, as he asserts. His perception of man's dominance over woman as a "deterioration," in contrast to a prior absolute equality of the sexes, raises similarly serious questions. $\mathrm{He}$ perceives this as a "deterioration in the human condition," one that apparently affects both sexes; I understand it as creating tension between them, in contrast to the previous peaceful equilibrium. The "deterioration" must have a motive, plausibly as a punishment for a sin, as he states that it "resulted from defiance of the divine will" — but whose sin? In any case, this "deterioration" affects man and woman equally, so why is it included in God's communication to or punishment of the woman? Further, as I discuss in the next chapter, why should the man, the primary sinner (as Sarna contends), be rewarded by becoming superior to the woman by ruling over her (Gen 3:16)? We have seen

\footnotetext{
74 Cassuto, Commentary on Genesis, 136.

75 Sarna, Genesis/בראשית, 22.

76 Ibid., 28.

77 See also 1 Tim 2:13-14: "For Adam was formed first, then Eve."
} 
that English legislators of the early modern era, for example, understood the consequences of woman's creation from man's body quite differently.

Modern commentators have attempted to diminish the sexual element of the reunification of man and woman and bolster the spiritual values of love and fidelity. With respect to the statement in Gen 2:24 that "the man leaves father and mother, loosing the strongest bodily and spiritual bonds" for the sake of the wife he has chosen, Westermann writes, "The love of man and woman receives here a unique evaluation." 78 Sarna conjectures that, in Gen 2:24, the narrator traces the existing custom of the man leaving his parents for the sake of his wife to God's original creative act; it is perceived "as part of the divinely ordained natural order."79

Sarna writes that דבק is used "to describe human yearning for God," and, by analogy, that "sexual relations between husband and wife do not rise above the level of animalism, unless they be informed by and imbued with spiritual, emotional and mental affinity." 80 Cassuto, too, attempts to promote the idea that Scripture minimizes the significance of the physical sexual relation and exalts the spiritual union, writing that "the reference [of the phrase 'he cleaves to his wife'] is not solely to sexual relations..., but also - and more especially - to the spiritual relationship." ${ }^{\prime 1}$ It is certainly legitimate for Cassuto to interpret Scripture according to his modern views, and to adduce scriptural support for them, but it should not be assumed that the ancient authors and their contemporary audiences interpreted Scripture, and specifically the Creation and Fall narratives, in ways that Cassuto and other scholarly commentators would prefer. In fact, Wevers presumes that the final clause of the Creation narrative in the LXX - "the two shall become one flesh"82 - refers to "the sexual union of man and wife." ${ }^{33}$ On the other hand, David Brewer writes that the addition of the phrase "the two" in the Lxx's translation of Gen 2:24, "so that it read 'they two shall become one flesh' ... became the basis for the New Testament teaching of monogamy by Jesus and Paul." ${ }^{\text {84 }}$ While it is true

\footnotetext{
78 Westermann, Genesis 1-11, 234.

79 Sarna, Genesis/בראשית, 23.

80 Ibid.

81 Cassuto, Commentary on Genesis, 137.

82 The LXx translates here, as on many other occasions, the Samaritan text, which adds משניהם, as we have seen above.

83 Wevers, Notes on Genesis, 35 .

84 David Instone Brewer, "Jewish Women Divorcing Their Husbands in Early Judaism: The Background to Papyrus Se'elim 13," HTR 92:3 (1999), 349-57 at 355 .
} 
that Mark 10:8 cites verbatim the Lxx text of Gen 2:24 with the addition "the two," it does not absolutely convey a divine prohibition of polygamy. The phrase could be understood as stating that at every union of a man with a woman, they become one flesh. In fact, Qumran scholars, who habitually adhere to a straightforward interpretation of the biblical texts, did not deduce their prohibition of polygamy from this verse but from Gen 1:27 (CD IV:21). In fact, Mark does not justify the prohibition of polygamy on the basis of the phrase "the two," but on his interpretation of Gen 2:24, as a divine command: "what God has joined, let no man put asunder" rather than as an aetiological explanation of the facts of life. Hence, the same interpretation could be made of the MT text, without the addition of the phrase "the two."

Before concluding this scrutiny of the biblical Creation narrative and its interpreters, I would like to discuss an interpretation of the phrase "and they will become one flesh" by Ramban, a traditional Jewish commentator of the Middle Ages, that can be perceived as having an affinity with modern scholarly interpretations emphasizing the spiritual bond of man and woman. He focuses his interpretation on the phrase ודבק באשתו "and he clings/sticks to his wife" as the key to understanding the verse. The human male leaves his family, sticks to his chosen wife, and creates a new family — a lasting partnership — whereas animals do not create lasting partnerships, but have sexual intercourse for procreative purposes with occasional females. Irrespective of the scientific correctness of Ramban's assumptions about animals' social life, his interpretation is remarkable for demonstrating a modern attitude on the part of a traditional medieval commentator.

\subsubsection{Male-Female Equality or Inequality as a Consequence of the Creation Narrative}

We have observed how the wide variety of interpretations of the narrative of the woman's creation represents the differing conceptions of their authors, rather than what the primary author of the narrative intended and its original audience understood. It seems plausible to assume that the various translators, who lived closer than modern scholars to the period of the primordial Torah's redaction, may have understood the intent of the apparently superfluous phrase "and the two will become one flesh" as pointing to the concrete sexual union of man and woman, rather than to their spiritual union. The woman's name denoting her creation from man, given her by Adam, demonstrates his dominant legal status, just as his naming of the animals (Gen 2:20) is a function of his God-granted dominion over them (Gen 1:28). This narrative is, in my opinion, the theological foundation of women's dependent legal 
status; ${ }^{85}$ she is not inferior to man, but she has no individual legal status. ${ }^{86}$ The narrative in Gen 2 thus overthrows the legal equality of man and woman as recorded in God's blessing and in their function and prerogatives in the world (Gen 1:28-31). ${ }^{87}$ The biblical texts, like classical writings, can be interpreted in different ways, as the rabbis acknowledged. ${ }^{88}$ Hence, in order to grasp the philosophy and intent of a biblical text - in our case, a narrative - we must analyse the biblical rules related to it, which may offer us the key to unlock the underlying conceptions. Indeed, the biblical narratives involving women in various circumstances and the relevant legal rules in Scripture demonstrate the subordinate legal status of women, and thus reveal the original intent of the author of the Creation narrative. ${ }^{89}$ In Jewish doctrine, everything is created by God. The life cycle and behaviour of every living being, like the constant operation of the whole of nature, is regulated by the divine rules of creation. According to a rabbinic midrash, the Torah was the divine master plan for Creation. ${ }^{90}$ An analysis of the biblical rules and narratives concerning women demonstrates women's legal dependence on their husbands in many instances, as I shall elaborate in this book. The wife obeys her husband, like one of his

85 Ronald A. Simkins, "Gender Construction in the Yahwist Creation Myth," in The Feminist Companion to the Bible (2nd ser.; ed. Athalya Brenner; Sheffield: Sheffield Academic Press, 1998) $32-51$ at 45 , writes that "the woman is taken me'iš 'from the man,' just as the rib is taken min ha adam 'from the man,' suggesting that the woman has her origin from the man and is thus dependent on the man. Yet the word play between 'iš and 'išša also suggests a complementary relationship between the man and the woman."

86 This conclusion is not the only possible one that may be deduced from this narrative, and many others have been offered.

$87 \quad$ Man and woman are equally commanded to fulfill the precept of procreation and have equal dominion over all other creatures and the privilege, denied to the other creatures, of enjoying the entire world's bounty. The rabbis contend that the procreation decree obligates only men (b. Yeb. 65b).

88 We read in b. Qidd. 20a: "Since these [biblical] verses can be interpreted both in a lenient and a strict way, why have you chosen to interpret them in a lenient way? Let us interpret them in a strict way."

89 Frymer-Kensky, In the Wake of the Goddesses, 128, writes that "Male dominance was assumed: it was part of the social order of the world that the Bible did not question." We agree that this was the real situation; however, I argue that the Bible's Creation narrative offers an explanation or justification for the existing male dominance, and confirms it as the God-given world order communicated to the woman in Gen 3:16: "and he will rule over you." Frymer-Kensky subsequently asserts, at 129, that God's communication to the woman is "part of the divine legitimation of the difficult but unquestioned condition of human existence," a statement somewhat similar to my own proposition.

9o We read in Gen. Rab. parsha 1 that God consulted the Torah and created the world. 
members, but this does not stigmatize her as inferior; in fact, a divorced or widowed woman becomes an individual legal personality - in the terminology of Roman law, sui juris "legally independent" — and her vows and obligations cannot be voided in her new circumstances (Num 30:10). ${ }^{91}$

The differentiation of the commutation payments for vows in Lev 27:2-7, which establishes higher amounts for men than for women, does not imply that a man is worth more than a woman; ${ }^{92}$ according to both traditional commentators and modern scholars, the different amounts are not based on an assessment of people's intrinsic value. Rabbinic halakhah discerns between the similar terms ערך and דמים regardless of any valuation, whereas the second, meaning money, relates to assessments of values. The use of one term or the other in a vow has legal consequences: if ערך is used, the one who makes the vow is assumed to refer to the scriptural fixed amounts, whereas the use of דמים is assumed to refer to the payment of the amount established by assessment. Therefore, if a man died before having fulfilled his vow, his heirs must pay it, like any other debts owed by their father, since his obligation was valid immediately after his pronouncement of a vow using ערד. If he had used דמים in his vow, his heirs would not have to pay: at the time of their father's death he had not yet incurred the obligation, since the assessment was not yet made ( $m$. Arak. 5:2). According to the rabbis, Scripture decrees fines based on assessments in some circumstances, but in others sets fixed amounts unrelated to the different monetary values. For example, if an ox kills a slave, whether male or female, its owner pays a fine of thirty shekels, although a male slave was probably worth more than a female slave. ${ }^{94}$

The orthodox scholar David Hoffmann follows the rabbinic interpretation and asserts that the worth of something dedicated to God is different from

$91 \quad$ M. B. Qam. 8:4, for example, discerns between the responsibility to redress damage done by a minor and that done by a married woman. Whereas the minor has no responsibility for what he has done, and does not pay for it when he grows up, the married woman, who does not pay for damages she inflicted as long as she is married, must redress them as a divorcée or widow.

92 See Noort, "The Creation," $6-7$, for scholarly opinions on this topic.

93 The use of דמים to mean "money" is not biblical; the word is used as such in the rabbinic literature and in modern Hebrew. Its root is דמים "similar/equivalent"; by association, דמים became "money," the equivalent paid for goods.

94 It is remarkable that the Code of Hammurabi also distinguishes a person who causes the death of another man's slave, and must compensate him with a slave of comparable value $(\S 231)$, from the one whose ox gores and kills another man's slave, and who must pay a fixed fine of twenty shekels of silver $\left(\S_{252}\right)$. 
the economic value of a person according to his physical strength and age. He notes that in a regular assessment one discerns between the value of a man in his early twenties and that of a man in his late fifties, as well as evaluating them on the basis of other criteria, whereas Scripture does not differentiate the amounts to be paid for commutation of a man's dedication to God or the Temple on that basis. ${ }^{95}$ Martin Noth understands the payments as a late provision enacted to release the person from the previous custom whereby someone dedicated to the sanctuary was set apart for perpetual auxiliary service, as in 1 Sam 1:11. ${ }^{96}$ The different assessments represent the value of the person's work, and a woman's work was worth less than a man's. He notes, however, that on this theory the assessed value of a child should be higher than that of an adult, since the child will ultimately work longer than a mature personunless one assumes, as Noth suggests, that the amounts indicated in Scripture are yearly payments and represent the value of the person's current work capacity. Karl Elliger offers a similar explanation of the various assessments and also assumes that the amounts represent yearly payments, which introduces a logical motive into the biblical rule. ${ }^{97}$ Therefore, a boy's work from the ages of five to twenty is worth more than that of a man over sixty, and that of an infant is the lowest. Thus, we observe that according to a broad range of commentators from a variety of periods and cultures, Lev 27's establishment of lower payments for the commutation of women's vows than for men's does not indicate man's superiority or woman's inferiority but, rather, relates to the values of their respective capacities for work..$^{98}$

The real value of a person, which has no association with money, is his or her life, and in this case Scripture equalizes man and woman, old and young: a murderer is executed regardless of whether the victim is man, woman, boy, or girl (Lev 24:17). This seems normal and logical to us, but it was not so in the surrounding cultures in ancient times. For example, the relevant rules from the Code of Hammurabi, from which Scripture has definitely appropriated to some extent, go in an opposite direction in this respect. According to the Code of Hammurabi $\S 210$, if a pregnant woman dies as a result of being struck by a

95 David Z. Hoffmann, Das Buch Leviticus (Hebrew trans. Zvi HarShefer and Ahron Lieberman; Jerusalem: Mossad Harav Kook, 1953 [Hebrew]).

96 Martin Noth, Leviticus: A Commentary (trans. J.E. Anderson; London: scm Press, 1965).

97 Karl Elliger, Leviticus (Tübingen: J.C.B. Mohr (Paul Siebeck), 1966 [German]).

98 Phyllis Bird, "Images of Women in the Old Testament," in Religion and Sexism (ed. Rosemary Redford Ruether; New York: Simon and Schuster, 1974) 41-88, at 55 states that the differential payments for the commutation of vows in Lev 27 "must have been in large part economic, though a psychological factor is also evident." 
man, the man's daughter is killed. This rule and the antecedent $§ 209$, which imposes a fine if the woman miscarries, have their parallel in Exod 21:22-23; whereas v. 22 also imposes a fine for the death of the fetus, v. 23 commands "a soul for a soul": the death of the perpetrator, not of his wife or daughter. In the Code of Hammurabi, then, a woman is worth less than a man, but not so in Scripture. Similarly, according to $\$ 228-29$, if a builder constructs a house in an unsatisfactory way, and in collapsing it kills the owner, the builder is executed; but if the owner's son is killed, the builder's son is executed, since he is worth less than the father. The Creation narrative makes no discrimination; all humanity was created in "the image of God" (Gen 1:27), and as their creation is equal, their inherent value is equal. Lev 24:17 explicitly states that anyone who takes a human life is to be put to death, with no exceptions; all are equal when it comes to the appreciation of life.

\subsection{Qumran's Possible Understanding of the Creation Narrative and Its Legal Ramifications}

The Qumran literature does not interpret biblical texts continuously, as the rabbis do; we can only attempt to deduce Qumranic interpretations of these texts from their relevant writings, sometimes from explicit dicta but mostly by conjecture from implicit texts. I attempt in this section to discern which rules and decrees pertaining to the status of women are drawn from the Creation narrative.

The text of 4 Q416 (4QInstr' ${ }^{b}$ ) 2iii:21-2iv:10 offers an explicit interpretation of the relevant biblical verses, leading to the halakhah of woman's submissiveness to man. As we observe, particularly from the phrase עזר בשרכה "the helper of your flesh," a logical variant on the biblical עזר כנגדו that emphasizes the carnal aspect of woman's creation from man, Qumran scholars considered that Gen 2:23-24, which asserts that woman was created from man, acknowledges that she becomes one flesh with the man at their marriage; thus, in becoming part of man's flesh, she loses her identity. The mandatory character of $4 \mathrm{Q} 416$ 4 QInstr ${ }^{b}$ indicates the legal relationship between man and woman and the man's dominion over his wife after their union. It is notable that Qumran scholars seem to have understood the divine guideline of woman's submission to her husband and her desire for him, not as punishment for her eating the prohibited fruit or for taking the initiative to make Adam eat it, as is commonly alleged, but simply as the consequence of her creation from man's rib, even though this utterance appears in Scripture as part of the Fall narrative (Gen 3:16b); I shall devote further attention to this issue in the next chapter. Marriage fulfills 
woman's inborn urge for reunion with man, from whom she was separated at her creation; she becomes bone of his bone and flesh of his flesh, as Adam declares on first seeing her. ${ }^{99}$ This is the mirror image of a rabbinic midrash explaining that man searches for what he lost at the creation of woman, the text of which is cited earlier in the chapter (p. 30).

Consequently, when a woman marries, she becomes part of her husband: she has no power of decision, not even over herself, and no responsibility. A person who lacks the right to carry out her own will has no responsibility, since she cannot carry out her wishes and obligations; her legal status, lacking the freedom to act, is like that of a slave, whose deeds are the responsibility of his owner. ${ }^{100}$ Hanna Cotton draws our attention to the fact that the Qumran rules give no indication of an age requirement for a woman to marry, ${ }^{101}$ whereas a minimum age of twenty is required for a man $\left(1 \mathrm{Q}_{2} 8^{\mathrm{a}}\right.$ $\left.\left(1 \mathrm{QS}^{\mathrm{a}}\right) \mathrm{I}: 9-11\right)$. This rule is the natural consequence of man's exclusive decisionmaking authority. The woman has no personal individual will and cannot determine anything, and her knowledge and wisdom as to what is right and wrong are therefore unnecessary for marriage and married life; since the man decides everything, he is responsible for his family and its behaviour in all respects. The complete integration of the woman's personality into her husband's is evident from various biblical texts, some of which are discussed in this chapter, and others which I shall quote and deliberate upon in diversified circumstances in the book.

The daughter of a priest, if she marries an Israelite, loses her hereditary right to eat the holy priestly tithes (terumah), because she becomes part of her Israelite husband (Lev 22:12). If she is divorced or widowed and has no children by her Israelite husband, and returns to her father's house, her right to eat the tithes is revalidated, since she is permanently detached from her husband's family (Lev 22:13). If, however, she has a son by her Israelite husband, she is apparently deemed to remain part of his family and is not permitted

99 In contrast to my understanding of the biblical expression "and they will become one flesh" as an abstract legal principle, Aharon Shemesh, "Women and Their Status in Society and Halakhah According to Qumran Literature," Yearbook of Bar Ilan University 30/31 (2006): $533-46$ at $533^{-}-39$ [Hebrew], seems to perceive it as a type of physiological factthat is, there is no way to divide between man and woman, due to the creation principle, as long as both live. For a more detailed analysis of this theory, see Chapter 6 pp. 244-247.

100 See note 91 on a married wife's responsibility for damage inflicted on others.

101 Encyclopedia of the Dead Sea Scrolls (ed. Lawrence H. Schiffman; New York: Oxford University Press, 200o) 981 . 
to eat the holy tithe. The complete integration of a woman into her husband and his family is thus evident. The biblical rule of Num 30:8 (appearing in its various ramifications in ${ }_{11} \mathrm{Q}_{19}$ (11QTemple ${ }^{\mathrm{a}}$ ) LIII:16-LIV:5 and parallels 4Q524 (4QTemple ${ }^{\mathrm{b}}$ ) and $\left.{ }_{11} \mathrm{Q}_{20}\left({ }_{11} \mathrm{QTemple}^{\mathrm{b}}\right) \mathrm{XVI}\right)$ establishes that a woman's father or husband can invalidate a vow or pledge made by her, even when it relates to her own person. ${ }^{102}$ She becomes an independent legal entity only when divorced or widowed (Num 30:10, referenced in 11 Q19 (11QTemplea) LIV:4-5) ${ }^{103}$ Likewise, other legal limitations on women are ramifications of their lack of an independent legal identity. J.E. Lapsley draws our attention to the fact that Rachel and Leah do not, and cannot, address their complaints directly to the offending party - their father, Laban — and consequently empower Jacob to defend their legal interests (Gen 31:14-16). ${ }^{104}$ On the other hand, Zelophehad's daughters bring their case before Moses (Num 27), and the two prostitutes dispute their conflict before Solomon (1 Kgs 3). The distinction here is that these latter women are not married - that is, not legally attached to men — whereas Rachel's and Leah's interests are understood to be equated with those of Jacob, their husband, who represents them in his quarrel with Laban.

102 It is not within the scope of my discussion here to elaborate on what type of vows these rules refer to, since some seem to limit man's authority to specific types of vows while others seem not to envisage any limitations on man's authority to annul all vows. For our present purposes, it suffices to demonstrate woman's lack of power to accomplish her vows against her husband's will.

103 The biblical text of Num 30:4 (v. 3 in KJV) repeats the condition on the father's right to annul his daughter's vows: "a young woman still living in her father's house," that is, while she is a minor. Scripture does not clarify whether the father's prerogative is restored if she returns to his house still as a minor but a divorcée or widowed; $b$. Yeb. 87a states, however, that his authority, once lost to her husband, is not restored, even if she is still a minor. This rule is logical since v. 10 (v. 9 in KJV), which sets the rule for a widow and a divorcée, does not indicate any limitation of its validity. Her right to eat terumah, however, is reinstated regardless of her age if she returns to her father's house as a divorcée or widow without children, as we read in Lev 22:13. The criteria for granting permission to a priest's daughter to eat holy food are distinct from those applicable to the father's authority to annul his daughter's vows.

104 J.E. Lapsley, "The Voice of Rachel: Resistance and Polyphony in Genesis 31:14-35," in The Feminist Companion to the Bible (2nd ser.; ed. Athalya Brenner; Sheffield: Sheffield Academic Press, 1998) 233-48 at 236-7. 


\section{Rabbinic Interpretation of the Creation Narrative: Positive and Negative Attitudes towards Women in Midrashim}

Since I have already cited rabbinic interpretations and legal repercussions, and shall discuss rabbinic viewpoints on and legal ramifications of the Fall narrative more extensively in Chapter 2 (and particularly on deductions from rabbinic texts and narratives in section 2.6), at this stage I shall simply quote a number of rabbinic midrashim on the Creation narrative, as a background for their later evaluation from a number of perspectives.

My first example demonstrates contrasting attitudes regarding the presumed intention and implementation of God's creation of woman, as an indication of her character. I refer to two consecutive midrashim in Gen. Rab. parsha 18:1 and 2. Parsha 18:1 states (paraphrased): ויבץ "And God built from the rib (Gen 2:22)," meaning that more wisdom was implanted into her than into the man. ${ }^{105}$ The midrash is inspired by the likeness of the verb בנה "to build," used in Gen 2:22, and the verb בינה "understanding, wisdom, intelligence," used in this homily. This extremely flattering portrayal of woman is immediately mitigated somewhat by Rabbi Jeremiah, who, while not contradicting the facts of the case, explains away the woman's apparent advantage: "Habitually the woman sits at home and the man goes to the marketplace and gains wisdom from social intercourse with people." As I understand Rabbi Jeremiah's pronouncement, God considered it necessary to give more wisdom to the woman initially because she will have no chance to develop it further, whereas the man will gain more wisdom later in life; hence, in reality, both will be equivalent in wisdom. Rabbi Jeremiah avoids directly contradicting Rabbi Jose's dictum that woman has more wisdom than man, but in essence grants an equal degree of wisdom to both sexes.

On the other hand, Gen. Rab. parsha 18:2 offers us a contrasting view of woman's character, based on the same biblical verse and the same use of ויבן, from the root בוץ "understanding" (in this case, "contemplating"). Parsha 18:2 states (paraphrased): Rabbi Joshua of Sakhnin said: ויבן "And God contemplated from which part of Adam he should create the woman: not from the head, so she should not be frivolous, nor from the eye, so she should not be flirting, nor from the ear, so she should not eavesdrop, nor from the mouth, so she should not be a gossip; not from the heart, so she should not be jealous,

105 A renowned late traditional commentator, known as Hatam Sofer from the title of his most revered work, comments on this dictum that it is amazing, since it is an obvious distortion of reality. He attempts to reconcile it with his views by means of psychological discourse and a classification of the different types of human wisdom. 
nor from the hand, so she should not be touching everything, nor from the leg, so she should not lightly open her legs, but from a place that is covered on a man, even when standing naked"; and at the creation of every part of her, God was saying: "be אשה צנועה a chaste woman."106 Rabbi Joshua proceeds to explain that notwithstanding God's intent, woman has all of the above defects. This extremely negative view of woman's character seems so ingrained in the author's mind that he overlooks his implicit affirmation that omnipotent God did not succeed in accomplishing his creation as intended-a statement bordering on heresy.

As another example of a contrasting view, we read in b. Ber. 61a: "[It is written] 'And God built [from] the rib' [the common interpretation of צלע]107]; Rav and Samuel [dispute from which part of Adam the woman was built:] one said from the face and the other said from the tail [hinting that Adam was created with a tail, like the animals]." The subsequent deliberations do not debate the deeper meaning of these opinions; they simply attempt to reconcile the dicta with the relevant biblical verses, with which they do not accord. I believe nevertheless that a different philosophical background underlay these pronouncements; I cannot see any other motive for the authors' interpretation, which disagrees with the common meanings of צלע, except to express their opinions about woman's characteristics as a result of her primeval source: one

106 I have translated the Hebrew צנע as "chaste," the common translation; not in the sense of abstaining from all sexual intercourse, however, but as morally pure in thought or conduct—decent, modest, and abstaining from unlawful sexual intercourse. The term צנע appears only twice in Scripture (Prov 11:2; Mic 6:8), and in both cases it means humility or restraint, having no association with abstention from sex. The NIV translates one as "humbly" and the other as "humility," appropriate to the context. The Lxx uses $\tau \alpha \pi \varepsilon v$ ś $^{\prime}$ "humble" in Prov, corresponding to the Hebrew צנועים, but not interpreted literally; and in

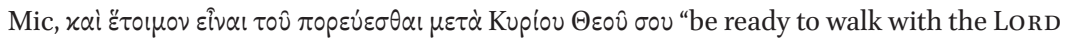
thy God," corresponding to the Hebrew והצנע לכת עם אלהיך. Both, however, are correct in their contexts. In rabbinic language, the subject of our study, צנלת לידת has acquired by extension many more meanings, including "putting aside/hiding" and "retire or withdraw," used metaphorically to portray modest behaviour in its various aspects. In consequence, it is used in some indirect associations with sex, as in our case צנועה, meaning the behaviour of a woman who is modest, hiding her body parts under her garments, and who lives a retired life in her house, avoiding mingling with other men. צנועה is used in a similar way in the midrash stating that God created her ממקום צנוע באדם "from the man's hidden side," withdrawn from view — a concept associated with modesty, humility, and decency. However, it is never associated with total abstention from sexual intercourse, which the rabbis opposed, as I argue elsewhere (see Chapter 7, pp. 270-272).

107 In Scripture, צלע means "side"; in the rabbinic literature, it primarily means "rib." See p. 20 for an analysis of this issue. 
positive, the other negative. As I have noted above, it is legitimate in the rabbis' midrashic system to have many interpretations of the same verse, including the two rabbinic assertions of Gen. Rab. parsha 18:1 and 2, one of which praises women for their inherent superior qualities while the other stigmatizes them.

On the other hand, many rabbinic texts express more positive views of women. For example, in $b$. Yeb. 62b we read that every man without a wife lives without joy, blessing, or goodness. The author of this maxim cites the biblical verses that are the source of his assertion. ${ }^{108}$ Another rabbi says that in the west (that is, in Israel, which is west of Babylon) they say that a man who has no wife is "without Torah, without a wall (a barrier that defends him from fornicating)"; he too supports his assertion with biblical citations. ${ }^{109}$ The rabbis do not claim that their assertions, even with respect to physical facts and occurrences, have been reached by empirical observation as in the modern physical sciences; rather, such assertions derive from study of the Bible, the fountain of all knowledge, in keeping with the rabbinic aphorism about diligently searching the Torah for guidance: "turn it and turn it, since everything is in it" ( $m$. Abot 5:22).

B. Yeb. 63a likewise stresses woman's significance for man: "Every man who has no wife is not a perfect Adam (human), as is written: 'He created them male and female... [and when they were created] he called them "Adam/ humans" ' " (Gen 5:2). This dictum raises some interpretational problems: it is not evident what this instance of "Adam" represents; I assume that it means "human." The emphasis on the fact that God called them both "Adam," ignoring the name, Eve, given to the woman by Adam, seems to support my supposition. ${ }^{110}$ B. Yeb. 63a offers us a different angle on woman's purpose and significant functions (paraphrased):

"I will make a helper [for him]" (Gen 2:18); in what consists her help? She turns raw substances brought home by him, such as grain and flax, into useful items. By this, she enlightens his life and keeps him going.

Another Rabbi declares: What is meant by "this is now" in Adam's pronouncement "bone of my bones and flesh of my flesh (Gen 2:23)?" It teaches that Adam had intercourse with every animal (wild and tame), but did not achieve satisfaction until he copulated with Eve.

108 Deut 14:26; Ezek 44:30; Gen 2:18.

109 In this case, Job 6:13; Jer 31:21.

110 It is commonly accepted that "Adam" in many instances means mankind, as also translated by the NIV here. 
Another imaginative story with two different versions attests to woman's valuable function; one version (Abot. R. Nat. Recension b, 8) emphasizes her eminent intrinsic value, the other (b. Sanh. 39a) the utility of her subservient status. (See translation of the midrashim on p. 23.) However, though both versions deem woman important for the benefit of man, the first compares her to a mere housemaid/servant, whereas the second likens her to a precious brick of gold.

A notably favourable portrayal of woman's significance emerges from the passages quoted above, but we should not ignore what they all have in common: in each case, woman's importance is defined by her relationship to man; her dedication for the benefit of man is her function in life and the purpose of her creation as man's helper (Gen 2:18). ${ }^{111}$ According to Abot R. Nat. Recension b, Chapter 8 (quoted in n. 7), woman was created by God at Adam's request; thus, satisfying his needs was the purpose of her creation. Like the Qumran authors, as noted above, the rabbis deduced from the Creation narrative both woman's dependence on man and, moreover, her purpose as being to please him. On the other hand, they do not deduce negative attributes of woman from the Creation narrative, with the exception of the midrash in Gen. Rab. parsha 18:2 (quoted above), which is influenced, I believe, by vilifying deductions from the rabbinic interpretation of the Fall narrative.

\subsection{Conclusion}

Our analysis of the three corpora-Scripture, rabbinic writings, and Qumranreveals the identical opinion in each on the legal status of a married woman: her utter dependence on her husband, and the loss of her individual legal status at her marriage. It does not, however, establish her inferiority to man or her permanent loss of status as a person, which she regains at her divorce or widowhood. Although the rabbis amalgamate in some of their midrashim elements of the Creation and Fall narratives, the woman's loss of the status of an individual legal entity derives entirely from the Creation narrative. The Fall narrative and its interpretations have other implications, primarily in terms of the social standing of women.

111 1 Cor 11:9: "Neither was the man created for the woman; but the woman for the man." 